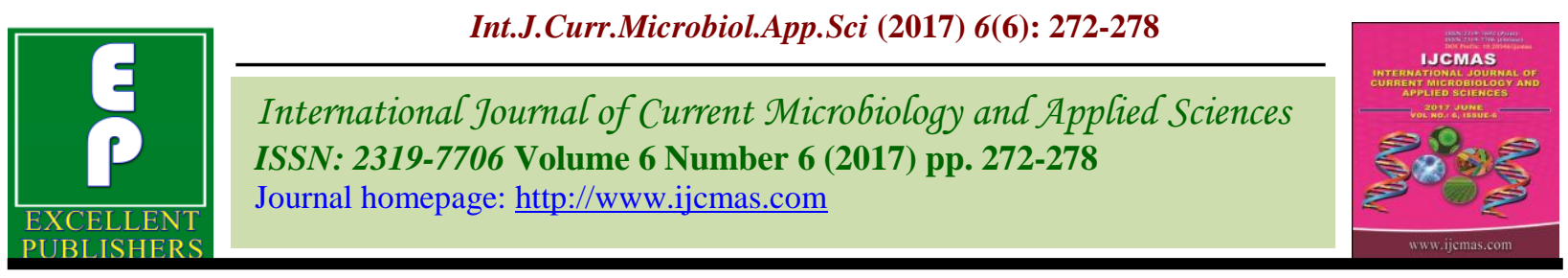

Original Research Article

https://doi.org/10.20546/ijcmas.2017.606.033

\title{
Evaluation of Chickpea Varieties under Different Moisture Stress Condition on Growth and Yield of Chickpea (Cicer arietinum L.)
}

\author{
Sunil Kumar Khoiwal, Ratan Lal Solanki* and M.P. Jain \\ ${ }^{1} \mathrm{KVK}$, Chittorgarh (Rajasthan), India \\ ${ }^{2}$ Department of Agronomy, College of Agriculture, Indore - (M.P.), India \\ *Corresponding author
}

\begin{abstract}
A B S T R A C T
A field experiment was conducted during rabi2013-14 at agronomy farm, college of agriculture, Indore, on medium black soil (Vertisols). The experiment was conducted in split-plot design replicated 3 times, keeping 3 moisture stress situation viz. S0 - Water

\section{Keywords}

Chickpea varieties, Different moisture stress,

Growth attributes, Yield and B:C ratio

Article Info

Accepted:

04 May 2017

Available Online:

10 June 2017 withheld after germination, S6L - Water withheld from 6 leaf stage and SFL - Water withheld from flowering in main-plots and 9 chickpea cultivars viz. V1 - Ujjain 21, V2 JAKI 9218, V3 - IG 593, V4 - JG 6, V5 - JG 16, V6 - JG 130, V7 - JG 412, V8 - JG 11 and V9 - KAK 2 in sub-plots. Crop was sown on 15-11-2013 and harvested on 29-032014. The rainfall of $46.8 \mathrm{~mm}$ in 3 days was received during cropping period. Plant height of chickpea was recorded highest with S0 - Water withheld after germination while it was recorded with V3 - IG 593 under chickpea varieties. Pod weight per plant was recorded significantly higher with S6L under moisture stress situations and with V9 - KAK 2 among different chickpea varieties. Seed yield of was obtained highest with moisture stress situation treatments SFL followed by S6L. SFL gave $68.47 \%$ higher production over S0 and S6L gave $19.51 \%$ higher production over S0, while SFL gave $40.97 \%$ more yield as compared to the seed yield achieved with S6L. Among the chickpea varieties, V5 - JG 16 produced highest seed yield followed by V6 - JG 130 followed by V8 - JG 11. Under various treatment combinations, the seed yield of chickpea was recorded highest under SFLX V5. B:C ratio was noted highest with SFL due to moisture stress situations while in case of chickpea varieties, maximum values were estimated under V5 - JG 16. It may be concluded from that the combination of moisture stress situation SFL - Water withheld from flowering and the chickpea variety V5 - JG 16 was found most suitable in terms of productivity and profitability.
\end{abstract}

\section{Introduction}

Pulse crops play an important role in Agriculture. Besides being rich in protein, they sustain productivity in cropping system. Their ability to use atmospheric nitrogen through biological nitrogen fixation is economically sounder and environmentally acceptable. Pulses are considered secondary to cereal crops and grown on marginal soils, as they are perceived to be low yielding and less remunerative crops. As a result, the growth rate of production of pulses in India, the major pulse growing country in the world is low compared to cereals. As a result of ever increasing population, availability of pulses shows sharp decline. Chickpea (Cicer arietinum L.) is the third most important food legume crop occupying first rank in area as well as production among the pulses grown in 
the country. Two main types of chickpea are recognized. Desi type with brown seed accounts for nearly $90 \%$ and Kabuli type with cream coloured bold seeds is grown in around $10 \%$ area. Nearly $90 \%$ of the crop is cultivated under rain-fed condition that is, mostly on receding soil moisture and on marginal lands. Chickpea is grown in tropical, sub-tropical and temperate regions. Kabuli type is grown in temperate regions while; the Desi type chickpea is grown in the semi-arid tropics. Historically India is the largest producer, consumer and importer of pulses. Although it is the world's largest pulses producer, India has been importing 3-4 million tons (MT) of pulses every year to meet its domestic demand. Madhya Pradesh is the major pulse producing state contributing a major share of $23 \%$ to the national chickpea production. In the year 2007, the area under chickpea increased to the tune of $2.56 \mathrm{~m}$ ha and yield was recorded to be $925 \mathrm{kgha}^{-1}$ (Ali and Shiv Kumar, 2007). This statistical data of area, production and productivity of chickpea clearly indicate that chickpea or pulse production for last three decades has remained more or less static fluctuating between 11 and 14.5 million tones as against a minimum requirement of about $17 \mathrm{~m}$ tones per annum. There are many constraints for its low productivity.

Drought is a major limiting factor in realizing crop productivity. It is known that chickpea thrives well under drought prone conditions. Moisture stress and high temperature during early seedling and seed filling stages are the major constraints of its low productivity. However, there is less variability for yield performance of chickpea genotypes under drought conditions. Different workers used different methods to evaluate genetic differences for drought tolerance.

Water stress is an important factor affecting partitioning of biomass. However, the influence of water deficit on distribution of assimilate depends on the stages of growth and relative sensitivity of various plant organs to water deficit. Greater proportions of current photo-synthetase are allocated to pods and seeds when the crop experiences moisture stress after flowering or when it was raised completely without irrigation (Deshmukh et al.,, 2004). The intensity of water stress experienced by crop during pod and seed growth is linearly proportional to the allocation of photo-synthetase to pods and seeds. Assimilate remobilization from source enables a plant to maintain assimilate supply to seed during period of low current assimilate availability (Kumar et al.,, 2001b). Water deficit increases the plants dependency on remobilization for seed filling. The development of moisture stress leads to a wide range of change in plant processes like diversion of biomass to undesirable plant parts. Therefore, the chickpea genotypes with better biomass partitioning and mobilization efficiency will be suitable for cultivation in the dry land areas.

Improving crop productivity under conditions of abiotic constraints in field is one of the major concerns in many areas of the world where legumes are grown.

\section{Materials and Methods}

A field experiment was conducted during rabi 2013-14 at college ofagriculture,Indore, on medium black soil (Vertisols), having 7.88 $\mathrm{pH}, 0.45 \%$ organic carbon, $232 \mathrm{kgha}^{-1}$ available nitrogen, $10.2 \mathrm{kgha}^{-1}$ available phosphorus and $540 \mathrm{kgha}^{-1}$ available potassium. The topography of the experimental area was fairly leveled. Indore is situated in Malwa Plateau in western parts of Madhya Pradesh on $22^{\circ} 43^{\prime} \mathrm{N}$ latitude and $75^{\circ} 66^{\prime} \mathrm{E}$ longitude with an altitude of $555.5 \mathrm{~m}$ above the mean sea level. This region enjoys sub tropical semi arid type climate with an average annual rainfall of $964 \mathrm{~mm}$, most of 
which is received during mid June to middle of September. Southwest monsoon is responsible for major part of the precipitation with occasional showers in winter. The mean minimum and maximum temperature ranges between $\quad 7^{\circ} \mathrm{C}-23^{\circ} \mathrm{C}$ and $23^{\circ} \mathrm{C}-43^{\circ} \mathrm{C}$, respectively. December and January are the coldest months. In summer, the maximum temperature seldom goes beyond $41.7^{\circ} \mathrm{C}$ in the month of May. The soil of the experimental field has been grouped under medium black (Vertisols), belonging to fine montmorillonitichyperthermic family of typical chromusterts predominantly clayey in texture. The surface soil samples $(0-30 \mathrm{~cm})$ were collected randomly with the help of soil auger before sowing from the experimental field and representative composite sample was made for the mechanical and chemical analysis. The field experiment was carried out in split plot design with twenty seven treatment combinations of three moisture stress situation in main plot and 9 chickpea varieties in sub plots in three replications.

\section{Results and Discussion}

\section{Yield attributing parameters and yield}

\section{Plant height (cm)}

The data presented in Table.1 shows that plant height of chickpea was found to be affected significantly by different moisture stress situations and chickpea varieties. It was recorded highest $(60.2 \mathrm{~cm})$ with $\mathrm{S} 0$ - Water withheld after germination followed by the height under S6L - Water withheld from 6 leaf stage. The lowest plant height of 46.79 $\mathrm{cm}$ was recorded under SFL - Water withheld from flowering. Behboudian et al., (2001) and Mafakheri et al., (2010) confirmed these findings.

Under chickpea varieties, the plant height was recorded significantly higher under V3 - IG $593(60.36 \mathrm{~cm})$ followed by V7 - JG 412
$(58.44 \mathrm{~cm})$ and recorded minimum under $\mathrm{V} 4$ $-\mathrm{JG} 6(52.24 \mathrm{~cm})$.

\section{Number of branches per plant}

The data presented in table 1 shows that number of branches plant ${ }^{-1}$ was found affected significantly only by chickpea varieties.

Moisture stress situations failed to influence the number of branches plant ${ }^{-1}$ significantly. However, the number of branches plant ${ }^{-1}$ was recorded slightly higher under S6L - Water withheld from 6 leaf stage as compared to the other moisture stress situations.

Under chickpea varieties, It was recorded highest of 10.07 with V8 - JG 11 followed by the number of branches plant-1 under V5 JG 16 (9.07). The lowest number of branches plant-1 of $6.07 \mathrm{~cm}$ was recorded under V4 JG 6.

\section{Number of nodules plant $^{-1}$}

Moisture stress situation and chickpea varieties influenced number of root nodule plant $^{-1}$ in chickpea significantly.

Under the treatment of moisture stress situations, it was recorded significantly higher with S6L - Water withheld from 6 leaf stage (19.19) followed by SFL- Water withheld from flowering (18.04) and recorded lowest with S0 - Water withheld after germination (15.29).

Under various varietal treatments, the chickpea variety V2 - JAKI 9218 gave the highest number of root nodules (32.09) which were significantly superior to other varieties. It was followed by number of root nodules under V3 - IG 593 (25.79). The least count of root nodules was recorded with V5 - JG 16 (6.01). 


\section{Number of pods plant ${ }^{-1}$}

Number of pods plant $^{-1}$ was not influenced significantly by moisture stress situations, chickpea varieties or interaction of these two. However the highest numbers of pods plant ${ }^{-1}$ were noticed with S6L - Water withheld from 6 leaf stage moisture stress situations. In chickpea varieties, it was recorded highest with V9 - KAK 2 followed by V7 - JG 412. Mhase et al., (2003) and Mafakheri et al., (2010) also supported these findings.

\section{Pod weight per plant (g)}

The data presented in table 1 shows that pod weight plant $^{-1}$ was affected significantly by moisture stress situations and chickpea varieties. Under moisture stress situations, it was recorded significantly higher with S6L Water withheld from 6 leaf stage $(26.99 \mathrm{~g})$ which was statistically at par with pod weight per plant with S0 - Water withheld after germination $(21.11 \mathrm{~g})$ but differed statistically with pod weight plant ${ }^{-1}$ under SFL- Water withheld from flowering. Among different chickpea varieties, the significantlyhigher pod weight plant $^{-1}$ was noticed with V9 - KAK 2 (33.57 g) which was statistically superior over all the other treatments. Minimum values were noticed under V4 - JG 6 (18.1 g). The findings of Mhas et al., (2003) are in conformity of the results.

Table.1 Plant height, number of branches, nodules, podsand pod weight per plant of chickpea under different moisture stress situation and varieties

\begin{tabular}{|c|c|c|c|c|c|}
\hline Treatments & $\begin{array}{l}\text { Plant height } \\
\text { (cm) }\end{array}$ & $\begin{array}{l}\text { Number of } \\
\text { branches } \\
\text { plant }^{-1}\end{array}$ & $\begin{array}{l}\text { Number of } \\
\text { nodules plant }^{-1}\end{array}$ & $\begin{array}{l}\text { Number of } \\
\text { pods plant }^{-1}\end{array}$ & $\begin{array}{l}\text { Pod } \\
\text { weight } \\
\text { plant }^{-1}(\mathrm{~g})\end{array}$ \\
\hline \multicolumn{6}{|l|}{$\begin{array}{l}\text { Moisture stress } \\
\text { situations }\end{array}$} \\
\hline $\begin{array}{l}\mathrm{S}_{0}-\text { Water withheld after } \\
\text { germination }\end{array}$ & 60.20 & 8.06 & 15.29 & 49.73 & 21.11 \\
\hline $\begin{array}{l}S_{6 L}-\text { Water withheld from } \\
6 \text { leaf stage }\end{array}$ & 59.52 & 9.13 & 19.19 & 53.53 & 26.99 \\
\hline $\begin{array}{l}\mathrm{S}_{\mathrm{FL}}-\text { Water withheld from } \\
\text { flowering }\end{array}$ & 46.79 & 7.17 & 18.04 & 51.96 & 18.55 \\
\hline SEm \pm & 1.14 & 1.04 & $\mathbf{0 . 0 5}$ & 3.67 & 1.94 \\
\hline $\mathrm{CD}(\mathbf{P}=0.5)$ & 4.47 & NS & 0.19 & NS & 5.97 \\
\hline \multicolumn{6}{|l|}{ Chickpea varieties } \\
\hline $\mathrm{V}_{1^{-}}$Ujjain-21 & 53.98 & 7.33 & 11.07 & 48.76 & 19.50 \\
\hline $\mathrm{V}_{2^{-}}$JAKI -9218 & 56.51 & 8.51 & 32.09 & 46.71 & 18.99 \\
\hline $\mathrm{V}_{3^{-}} \mathrm{IG}-593$ & 60.36 & 7.82 & 25.79 & 39.13 & 20.99 \\
\hline $\mathrm{V}_{4^{-}}$JG-6 & 52.24 & 6.07 & 17.21 & 38.63 & 18.10 \\
\hline $\mathrm{V}_{5^{-}} \mathrm{JG}-16$ & 52.89 & 9.07 & 6.01 & 52.93 & 22.71 \\
\hline $\mathrm{V}_{6^{-}} \mathrm{JG}-130$ & 54.89 & 6.69 & 12.77 & 54.44 & 26.17 \\
\hline $\mathrm{V}_{7^{-}} \mathrm{JG}-412$ & 58.44 & 8.49 & 17.78 & 62.80 & 20.88 \\
\hline $\mathrm{V}_{8^{-}} \mathrm{JG}-11$ & 53.56 & 10.07 & 13.18 & 50.13 & 19.04 \\
\hline $\mathrm{V}_{9^{-}} \mathrm{KAK}-2$ & 56.67 & 9.04 & 21.68 & 72.11 & 33.57 \\
\hline SEm \pm & 1.73 & 0.86 & 0.12 & 8.57 & 2.99 \\
\hline $\mathrm{CD}(\mathrm{P}=0.5)$ & 4.93 & 2.44 & 0.34 & NS & 8.50 \\
\hline
\end{tabular}


Table.2 Seed index, number of seeds $\operatorname{pod}^{-1}$, seed and biological yield plant ${ }^{-1}$, Seed and biological yield $\left(\mathrm{kg} \mathrm{ha}^{-1}\right)$, Harvest index and B: C ratio of chickpea Under different moisture stress situation and varieties

\begin{tabular}{|c|c|c|c|c|c|c|c|c|}
\hline Treatments & $\begin{array}{l}\text { Seed } \\
\text { index } \\
\text { (g) }\end{array}$ & $\begin{array}{l}\text { Number } \\
\text { of Seeds } \\
\text { pod }^{-1}\end{array}$ & $\begin{array}{l}\text { Seed yield } \\
\text { plant }^{-1}(\mathrm{~g})\end{array}$ & $\begin{array}{l}\text { Biologica } \\
\text { l yield } \\
\text { plant }^{-1} \\
\text { (g) }\end{array}$ & $\begin{array}{l}\text { Seed } \\
\text { yield } \\
\left.\text { (kgha }^{-1}\right)\end{array}$ & $\begin{array}{l}\text { Biologic } \\
\text { al } \\
\text { yield }(k g \\
\left.h^{-1}\right)\end{array}$ & $\begin{array}{l}\text { Harves } \\
t \text { Index } \\
(\%)\end{array}$ & $\begin{array}{l}\text { B: C } \\
\text { ratio }\end{array}$ \\
\hline \multicolumn{9}{|l|}{$\begin{array}{l}\text { Moisture stress } \\
\text { situations }\end{array}$} \\
\hline $\begin{array}{l}\mathrm{S}_{0}-\text { Water withheld } \\
\text { after germination }\end{array}$ & 28.65 & 1.03 & 15.89 & 36.93 & 1024.54 & 3939.81 & 26.30 & 1.75 \\
\hline $\begin{array}{l}S_{6 L}-\text { Water withheld } \\
\text { from } 6 \text { leaf stage }\end{array}$ & 36.66 & 1.01 & 21.96 & 45.08 & 1224.42 & 4446.76 & 27.85 & 2.00 \\
\hline $\begin{array}{l}S_{\mathrm{FL}}-\text { Water withheld } \\
\text { from flowering }\end{array}$ & 28.11 & 1.01 & 13.90 & 29.04 & 1726.04 & 3953.70 & 44.28 & 2.63 \\
\hline SEm \pm & 4.64 & 0.01 & 0.79 & 2.56 & 26.88 & 145.21 & 0.93 & 0.04 \\
\hline $\mathrm{CD}(\mathrm{P}=0.5)$ & NS & NS & 3.12 & 10.06 & 105.52 & NS & 3.67 & 0.16 \\
\hline \multicolumn{9}{|l|}{ Chickpea varieties } \\
\hline $\mathrm{V}_{1}$ - Ujjain-21 & 18.06 & 1.00 & 15.80 & 32.86 & 1374.44 & 3986.11 & 34.20 & 2.16 \\
\hline $\mathrm{V}_{2^{-}}$JAKI -9218 & 41.83 & 1.00 & 15.52 & 34.63 & 1294.10 & 4263.89 & 30.39 & 2.05 \\
\hline $\mathrm{V}_{3}-\mathrm{IG}-593$ & 35.33 & 1.02 & 14.98 & 37.51 & 1184.03 & 4138.89 & 30.22 & 1.89 \\
\hline $\mathrm{V}_{4^{-}}$JG-6 & 34.25 & 1.04 & 13.72 & 33.53 & 1103.47 & 4138.89 & 27.07 & 1.77 \\
\hline $\mathrm{V}_{5^{-}} \mathrm{JG}-16$ & 21.11 & 1.02 & 18.69 & 36.04 & 1656.25 & 4680.56 & 35.93 & 2.60 \\
\hline $\mathrm{V}_{6^{-}} \mathrm{JG}-130$ & 25.94 & 1.04 & 23.39 & 38.93 & 1573.06 & 4277.78 & 38.43 & 2.47 \\
\hline $\mathrm{V}_{7}-\mathrm{JG}-412$ & 28.17 & 1.00 & 16.30 & 33.38 & 1130.00 & 3493.06 & 33.87 & 1.79 \\
\hline $\mathrm{V}_{8^{-}} \mathrm{JG}-11$ & 24.94 & 1.00 & 11.32 & 31.18 & 1463.82 & 4152.78 & 35.52 & 2.30 \\
\hline $\mathrm{V}_{9-} \mathrm{KAK}-2$ & 50.61 & 1.02 & 25.50 & 55.11 & 1145.83 & 3888.89 & 29.68 & 2.08 \\
\hline SEm \pm & 8.19 & 0.02 & 1.73 & 4.99 & 77.22 & 216.63 & 2.46 & 0.12 \\
\hline $\mathrm{CD}(\mathbf{P}=\mathbf{0 . 5})$ & NS & NS & 4.93 & NS & 219.60 & 616.08 & 7.00 & 0.33 \\
\hline
\end{tabular}

\section{Seed index}

Seed index was not influenced significantly by moisture stress situations and chickpea varieties. However the highest seed index was noticed with S6L - Water withheld from 6 leaf stage moisture stress situations. In chickpea varieties, it was recorded highest with V9 - KAK 2 followed by V2 - JAKI 9218.

\section{Number of seeds pod $^{-1}$}

Number of seeds pod-1 was not influenced significantly by moisture stress situations and chickpea varieties. The highest numbers of seeds pod $^{-1}$ were registered with S0 - Water withheld after germination moisture stress situations. In chickpea varieties, it was recorded highest with V4 - JG 6 and V6-JG 130.

\section{Seed and biological yield per plant (g)}

Among different moisture stress situations, the maximum values of seed yield plant- 1 and biological yield plant ${ }^{-1}$ S6L - Water withheld from 6 leaf stage (21.96 and $45.08 \mathrm{~g}$ ) followed by S0 - Water withheld after germination (15.89 and $36.93 \mathrm{~g}$ ) respectively. 
The moisture stress situations SFL- Water withheld from flowering resulted into the lowest seed yield per plant and biological yield per plant (13.9 and $29.04 \mathrm{~g})$. Behboudian et al., (2001) and Mhase et al., (2003) reported similar findings.

Under chickpea varieties, the differences in biological yield plant ${ }^{-1}$ were not statistically significant; while the seed yield plant $^{-1}$ differed significantly. The maximum seed yield plant ${ }^{-1}$ and biological yield plant ${ }^{-1}$ were found to be associated with V9 - KAK 2 (25.5 and $55.11 \mathrm{~g}$ ) followed by V6 - JG 130 (23.39 and $38.93 \mathrm{~g})$. The values of both yields were recorded lowest with V8 - JG 11 (11.32 and $31.18 \mathrm{~g}$ ) Many researchers viz. Shukla and Babbar (2011) and Srinivas et al., (2005) also reported similar findings.

\section{Seed and biological yield (kg/ha)}

Seed yield of chickpea with SFL- Water withheld from flowering (1726.04 $\left.\mathrm{kgha}^{-1}\right)$ was recorded significantly higher than rest of moisture stress situations. S6L - Water withheld from 6 leaf stage gave the seed yield of $1224.42 \mathrm{kgha}^{-1}$ remained at second position and S0 - Water withheld after germination registered with the lowest seed yield of $1024.54 \mathrm{kgha}^{-1}$. All differed significantly with each other. SFL gave $68.47 \%$ higher production over S0 and S6L gave $19.51 \%$ higher production over S0, while SFL gave $40.97 \%$ more yield as compared to the seed yield achieved with S6L.

Among the chickpea varieties, V5 - JG 16 gave the highest seed yield $\left(1656.25 \mathrm{kgha}^{-1}\right)$ followed by V6 - JG 130 (1573.06 kg/ha). V8 - JG 11 was registered as the next variety with the seed yield of $1463.82 \mathrm{kgha}^{-1}$.

\section{Harvest Index (\%)}

The data presented in table 1 revealed that the harvest index was significantly higher with
SFL- Water withheld from flowering (44.28 $\%$ ) and minimum in S0 - Water withheld after germination $(26.3 \%)$ under moisture stress situations treatment. Under chickpea varieties, it was recorded statistically higher with V6 - JG 130 (38.43\%) followed by V5 - JG 16 (35.93 \%). Minimum harvest index was found in V4 - JG $6 \quad(27.07$ $\%)$. Pouresmaeila (2012) and Yadava and Singh (2007) also reported similar findings.

\section{Benefit cost ratio ( $\mathrm{B}: \mathrm{C}$ ratio)}

$\mathrm{B}$ : $\mathrm{C}$ ratio under moisture stress situations was influenced the significantly and it was recorded highest SFL- Water withheld from flowering (2.63) followed by S6L - Water withheld from 6 leaf stage (2.00). The lowest $\mathrm{B}$ : $\mathrm{C}$ ratio was found $\mathrm{S} 0$ - Water withheld after germination (1.75). In chickpea varieties, maximum $\mathrm{B}$ : $\mathrm{C}$ ratio was found with V5 - JG 16 (2.6) followed by V6 - JG 130 (2.47). Lowest values of $B$ : $C$ ratio was recorded under V4 - JG 6 (1.77). Srinivas et al., (2005) and many other researcher reported similar effects on economic parameters.

It may be concluded from the results obtained from the one season experiment on moisture stress situations and varieties in chickpea that the seed yield of chickpea was obtained highest with moisture stress situation treatment SFL- Water withheld from flowering and the chickpea variety V5 - JG 16. Thus, the combination of moisture stress situation SFLX V5 (SFL- Water withheld from flowering in variety V5 - JG 16) was found better in terms of productivity and profitability.

\section{References}

Ali, M. and Kumar, S. (2007). Chickpea research in India: An overview. IIPR, Kanpur, India. pp 1-13 
Behboudian M Hossein; Qifu Ma; Neil C Turner and Jairo A Palta (2001). Reactions of chickpea to water stress: yield and seed composition. Journal of the Science of Food and Agriculture.81 (13): 1288-1291

Deshmukh, D. V., Mhase, L.B. and Jamadagni, B. M. (2004). Evaluation of chickpea genotypes for drought tolerance. Indian J. Pulses Res., 17: 4749.

Gupta, S. C.; Rathore, A. K.; Sharma, S. N.; and Saini, R. S. (2000).Reponse of chickpea cultivars to water stress.Indian J. Plant Physiol., 5 (3):274- 276.

Kumar, S.; P. P. Arora and A. S. Jeena (2001b). Correlation analysis in chickpea. Agri Sci. Digest.22 (2): 134135

Mafakheri, A.; Siosemardeh, B.; Bahramnejad, P. C. and Struik, Y. S. (2010). Effect of drought stress on yield, proline and chlorophyll contents in three chickpea cultivars. Australian J. Crop Sci., 4 (8):580-585.

Mhase, L.B.; Sahane, D.V. and Jamadagni, B.M. (2003).Varietal improvement of chickpea for rainfed and late sown condition. National Symposium on Pulses for Crop Diversification and National Resources Management; IIPR, Kanpur; December, 20- 22: 39.

Pouresmaeil M.; Khavari-Nejad R.; Mozafari J.; Najafi F.; Moradi F. and Akbari M. (2012).Identification of drought tolerance in chickpea (Cicer arietinum L.) landraces.Crop Breeding Journal2 (2): 101-110.

Shukla N. and Babbar, A. (2011). Association analysis of morpho-phenological traits on yield in chickpea lines evaluated in normal and heat stress envoirnments. J.N.K.V.V. Res. J., 45 (1): 52-57.

Srinivas, T.; Obaiah, M.C. and Moula, S.P. (2005).Performance of Kabuli chickpea cultivar KAK 2 in rainfed black soils of Prakasam Distirct, Andhra Pradesh, India.Intl. Chickpea and Pigeonpea Newsletter, 12: 9-11.

Yadava, H. S. and R. P. Singh (2007).Assessment of traits determining drought and temperature tolerance in Chickpea. J. Of Food Legumes21 (2): 99- 106.

\section{How to cite this article:}

Sunil Kumar Khoiwal, Ratan Lal Solanki and Jain M. P. 2017. Evaluation of Chickpea Varieties under Different Moisture Stress Condition on Growth and Yield of Chickpea (Cicer arietinum L.). Int.J.Curr.Microbiol.App.Sci. 6(6): 272-278.

doi: https://doi.org/10.20546/ijcmas.2017.606.033 